\title{
Tannins Compound in Soga Tingi Bark (Ceriops Tagal) as Natural Dyes
}

\author{
Paryanto $^{1 *}$, Sunu Herwi Pranolo, Ari Diana Susanti ${ }^{1}$, Bintang Timur Putrikatama ${ }^{1}$, \\ I.R.Qatrunada ${ }^{1}$, Angga Dwi Wibowo ${ }^{2}$ \\ ${ }^{1}$ Chemical Engineering, Faculty of Engineering-Sebelas Maret University, Surakarta \\ ${ }^{2}$ S1 Chemistry Study Program, Faculty of Mathematics and Natural Sciences, \\ Gadjah Mada University,Yogyakarta
}

\begin{abstract}
In general, natural dyes for textile materials are obtained from extracts part of the plants such as roots, wood, leaves, seeds, and flower. Textile industry especially batik craftsman, have known many plants that can dye textile materials, such as indigo (indigofera), soga tingi bark (Ceriops tagal), tegeran wood (Cudraina javanensis), turmeric (Curcuma), tea (The), noni root (Morinda citrifelia), soga jambal bark (Pelthophorum ferruginum), kesumba (Bixa orelana), and guava leaf (Psidiumguajava). Soga tingi bark chosen because it can produce tannins which can be used as natural dyes. The purpose of this research was to obtained tannin content in soga tingi bark as qualitatively and quantitatively. The analysis carried out is FTIR and HPLC method. FTIR analysis carried out to determine of the compounds contained in the soga tingi bark extraction. Based on FTIR analysis it can be seen that there are $\mathrm{O}-\mathrm{H}$ and $\mathrm{N}-\mathrm{H}$ group in the wavenumber $3375,13 \mathrm{~cm}^{-1}$. C $=\mathrm{O}$ bond at wavenumber $1739,16 \mathrm{~cm}^{-1} . \mathrm{C}=\mathrm{C}$ bond at wavenumber 1624,31 $\mathrm{cm}^{-1}$. C-H bond at wavenumbers $2970,72 \mathrm{~cm}^{-1}, 1456,39 \mathrm{~cm}^{-1}$, and $1365,74 \mathrm{~cm}^{-1} . \mathrm{NO}_{2}$ bond at wavenumber 1365,74 $\mathrm{cm}^{-1}$. C-N bond at wavenumbers $1228,69 \mathrm{~cm}^{-1}$ and $1217,34 \mathrm{~cm}^{-1}$. And C-O bond at wavenumbers $1228,69 \mathrm{~cm}^{-1}, 1217,34 \mathrm{~cm}^{-1}$, and 1052,3 $\mathrm{cm}^{-1}$. While HPLC analysis carried out to determine contains tannin level in the soga tingi bark extraction. HPLC conditions used are Flowrate: $1 \mathrm{~mL} / \mathrm{min}$, Mobile phase: $\mathrm{MeOH}: \mathrm{H}_{2} \mathrm{O}$ (50:50), $\lambda: 271 \mathrm{~nm}$ and Column: C18, $250 \mathrm{~mm}$. Based on HPLC analysis it is known that the contains tannin level in the soga tingi bark extraction is $22,44 \mathrm{ppm}$.
\end{abstract}

Keywords: cerios tagal, extraction, tannin

EQUILIBRIUM Volume 5 No.1 July 2021

Online at http://equilibrium.ft.uns.ac.id 


\section{INTRODUCTION}

Synthetic dyes harms the environment. In synthetic dyes, contains sulfur, naphthol, vat dyes, nitrates, acetic acid, soaps, chromium compounds, and heavy metals like copper, arsenic, lead, cadmium, mercury, nickel, and cobalt and certain auxiliary chemicals all collectively make the effluent highly toxic. Other harmful chemicals present in the water may be formaldehyde-based dye fixing agents, hydrocarbon-based softeners, and nonbiodegradable dyeing chemicals [4]. These chemicals will threaten human health and environmental sustainability if allowed to be used continuously. In the green consumers era, interest in natural dyes grew as an alternative to synthetic dyes. Natural dyes are alternatives that are non-toxic, renewable, easily degraded and environmentally friendly [16]. This matter for the challenge for the textile industry to raise environmental issues effort to maintain its existence. Visalakshi and Jawaharlal (2013) state that natural dyes can be obtained from plants, animals or minerals [15].

Almost all parts of a plant when extracted can produce dyes, such as: flowers, fruit, leaves, seeds, bark, stems and roots [10]. Natural dyes for textile materials are obtained from extracts part of the plants such as roots, woods, leaves, seeds, and flowers. Textile industry especially batik craftsman, have known many plants that can dye textile materials, such as indigo (indigofera), soga tingi bark (Ceriops tagal), tegeran wood (Cudraina javanensis), turmeric

(Curcuma), tea (The), noni root (Morinda citrifelia), soga jambal bark (Pelthophorum ferruginum), kesumba (Bixa orelana), and guava leaf (Psidiumguajava) [13]. Plants that can be extracted into dyes are very diverse, one of them is a soga tingi bark. Tingi tree (Ceriops tagal) is a very potential source of tannins and this tree is a mangrove species [12]. Tall wood is used as firewood while the bark is used as a batik dye for soga color mix (tegeran wood, high bark, and jambal) [5].

Soga tingi bark produces tannins which are often to use as tanner material and also coloring agents for paint [3]. Tannins from soga tingi bark (Ceriops tagal) can vary, from $13 \%$ to more than $40 \%$ a common and important feature of mangrove bark. These tannins are included in the group of condensed tannins procyanidin type, so dying with soga tingi bark gives a reddish-brown color [3]. Tannin is a very complex component of organic substances, consisting of phenolic compounds that are difficult to separate and difficult to crystallize, precipitate proteins from their solutions and compound with these proteins [2].

Until now the most frequently used separation method is the solvent extraction method because of its effectiveness and efficiency compared to other separation methods [14]. According to Purnomo (2004) natural dyes can be obtained by extracting from various parts of the plant using water solvents at high or low temperatures [11].Soga tingi bark are used as dyes because they contain tannins. Tannins extract was obtained by the extraction method [7].

The purpose of this research was to obtained tannin content in soga tingi bark as qualitatively and quantitatively. The analysis carried out is FTIR and HPLC method

\section{MATERIAL AND METHOD}

\section{Materials and tools}

The ingredients used are Soga tingi bark (Ceriops tagal) obtained from Cilacap, Water obtained from the Process Laboratory of Chemical Engineering Sebelas Maret University Surakarta.

The tools used are Stirring motor,Mercury stirrer,Beaker glasses,Elektric stove,Thermometer,Stative, Spectrophotometer (FTIR) Fourier Transform Infra-Red merk perkin elmer type frontier in the Laboratory of the Faculty of Mathematics and Natural Sciences, Semarang State University and High-Performance Liquid Chromatography (HPLC) perkin elmer aitus A-10 in the Integrated Laboratory of the Faculty of Mathematics and Natural Sciences Sebelas Maret University Surakarta.

\section{Procedure}

The first step is the manufacture of natural dyes by mixing 20 grams of soga tingi bark (Ceriops tagal) added with a water solvent at a ratio of 1:10 to the ingredients [8]. Furthermore, extraction was carried out for 30 minutes at a temperature of $96^{\circ} \mathrm{C}$ and the motor stirring rotation was $343 \mathrm{rpm}$. The extract obtained as much as $40 \mathrm{~mL}$, then tested with FTIR (Fourier Transform Infra-red) and HPLC (High-Performance Liquid Chromatography). The tannin levels in the soga can be calculated by the equation 


$$
\text { Tannin content }=\frac{\text { Wide sample area }}{\text { Wide standard area }} x \text { Standard consentration } x \text { dilution factor }
$$

\section{RESULT AND DISCUSSIONS}

From the FTIR spectroscopy test, a sample of soga tingi bark (Ceriops tagal) obtained the infrared spectrum as shown in Figure 1.

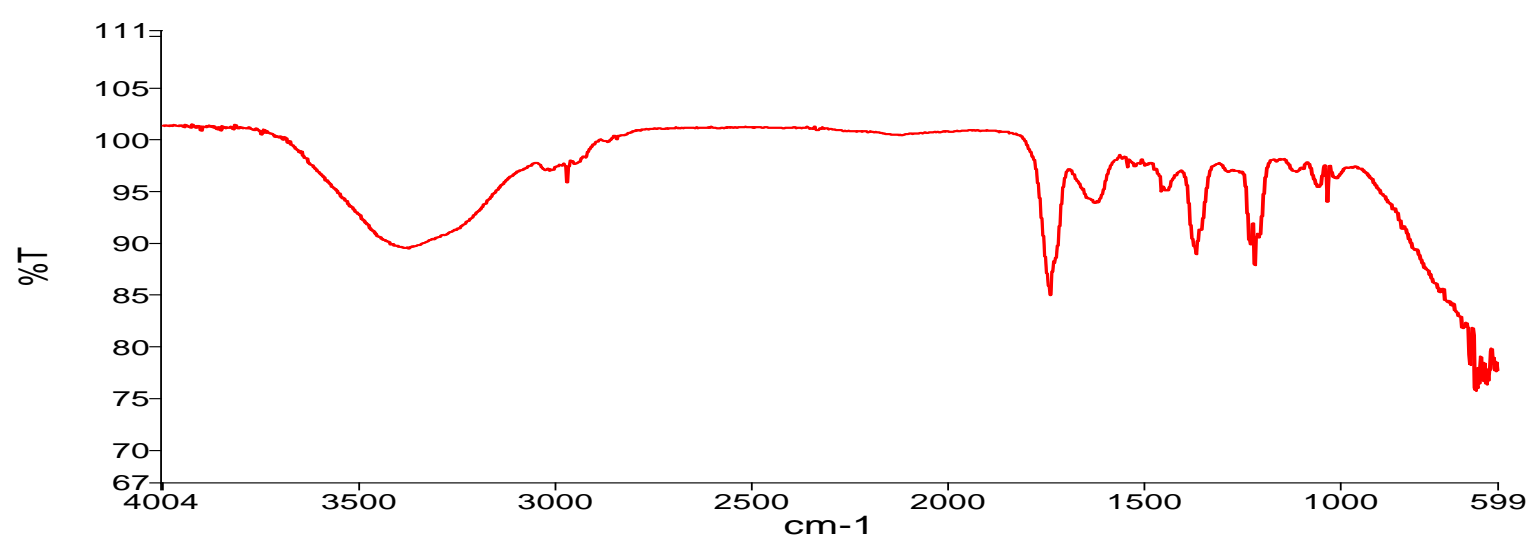

Figure 1. Infrared spectrum of soga tingi bark (Ceriops tagal)

Table 1. Soga tingi bark absorption area (Ceriops tagal)

\begin{tabular}{lll}
\hline Absorption area $\left(\mathrm{cm}^{-1}\right)$ & Ikatan & \multicolumn{1}{c}{ Compound type } \\
\hline 3375,13 & O-H & Phenol \\
& N-H & Amina, Amida \\
2970,72 & C-H & Alkane \\
1739,16 & C=O & Aldehyde, Ketone, Carboxylic acid, Ester \\
1624,31 & $\mathrm{C}=\mathrm{C}$ & Alkene \\
1456,39 & $\mathrm{C}-\mathrm{H}$ & Alkane \\
1365,74 & $\mathrm{C}-\mathrm{H}$ & Alkane \\
& $\mathrm{NO} 2$ & Senyawa Nitro \\
1228,69 & $\mathrm{C}-\mathrm{N}$ & Amina, Amida \\
& $\mathrm{C}-\mathrm{O}$ & Alcohol, Ether, Carboxylic acid, Ester \\
1217,34 & $\mathrm{C}-\mathrm{N}$ & Amina, Amida \\
& $\mathrm{C}-\mathrm{O}$ & Alcohol, Ether, Carboxylic acid, Ester \\
1052,3 & $\mathrm{C}-\mathrm{O}$ & Alcohol, Ether, Carboxylic acid, Ester \\
\hline
\end{tabular}

FTIR spectroscopy test results are shown in Table 1 which shows the absorption at different wavenumbers. $\mathrm{O}-\mathrm{H}$ and $\mathrm{N}-\mathrm{H}$ groups exist in the wavenumber $3375,13 \mathrm{~cm}^{-1} . \mathrm{C}=\mathrm{O}$ bond at wavenumber $1739,16 \mathrm{~cm}^{-1} . \mathrm{C}=\mathrm{C}$ bond at wavenumber $1624,31 \mathrm{~cm}^{-1}$. C-H bond at wavenumbers $2970,72 \mathrm{~cm}^{-1}, 1456,39$ $\mathrm{cm}^{-1}$, and 1365,74 $\mathrm{cm}^{-1}$. $\mathrm{NO}_{2}$ bonding at wavenumber $1365,74 \mathrm{~cm}^{-1}$. C-N bonding at wavenumbers 1228,69 $\mathrm{cm}^{-1}$ and $1217.34 \mathrm{~cm}^{-1}$. C-O bonding at wavenumbers $1228,69 \mathrm{~cm}-1,1217.34 \mathrm{~cm}^{-1}$ and $1052,3 \mathrm{~cm}^{-1}$. From the results of these tests it can be seen that in the soga tingi bark (Ceriops tagal) produces functional groups that contain tannin compounds. When compared with the research conducted by Kasmudjiastuti (2014) on the characterization of high bark as a tanning agent, the FT-IR spectrum of high bark containing tannins is as follows: hydroxyl group $(\mathrm{rO}-\mathrm{H} ; \mathrm{vN}-\mathrm{H})$ in the area $(3467,418-3057,025) \mathrm{cm}^{-1}$, aromatic group $(\mathrm{rC}-\mathrm{H})$ in the area of $2875.733 \mathrm{~cm}^{-1}, \mathrm{rC}=\mathrm{O}$ (ester group in tanned material) in the area $(1747,442-1612,422) \mathrm{cm}$ - 
${ }^{1}, \mathrm{v}$-OH; R-COO- in the area of $1444,626 \mathrm{~cm}^{-1}$ and $\mathrm{v}$ (SO4) 2-; R-SO3; R-SO3H in the area $(1112,823-$ $1062,729) \mathrm{cm}^{-1}$.

The FTIR spectrum results obtained in this study are almost the same as the research spectrum data by Kasmudjiastuti (2014), obtained tannin function groups in bark soga are hydroxyl groups $(\mathrm{OH})$, aromatic groups $(\mathrm{CH})$, ester groups $(\mathrm{C}=\mathrm{O})[5]$.

This was confirmed by Marais et al. (2006) revealed that flavonone is a building unit of proanthocyanidin compounds which are condensed tannins. Parubak (2013) who found that the flavonoid compounds from the flavonone group had $\mathrm{OH}$ bound functional groups, aliphatic $\mathrm{CH}, \mathrm{C}=\mathrm{O}, \mathrm{C}=\mathrm{C}$ Aromatic, $\mathrm{C}-\mathrm{O}$ and $\mathrm{C}$ - $\mathrm{H}$ aromatics [6]. HPLC test was carried out at the Flowrate condition: $1 \mathrm{~mL} / \mathrm{min}$, Motion phase: $\mathrm{MeOH}$ : $\mathrm{H}_{2} \mathrm{O}$ (50:50), $\lambda: 271 \mathrm{~nm}$ and Column: C18, $250 \mathrm{~mm}[9]$.

From the HPLC (High-Performance Liquid Chromatography) test of soga tingi bark (Ceriops tagal), chromatograms were obtained as shown in Figures 5 and 6.

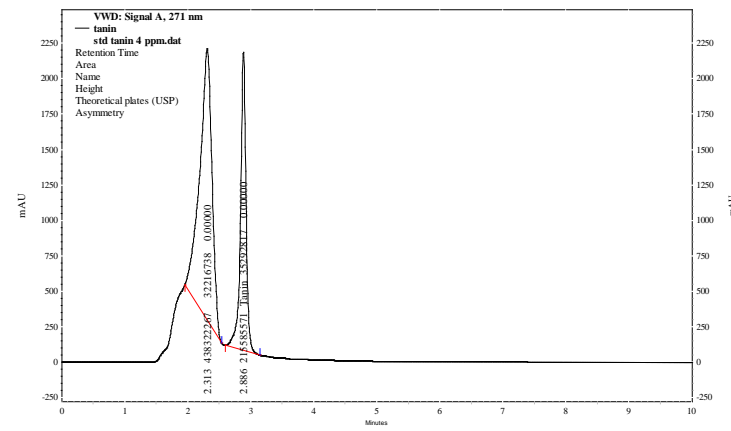

Figure 2. Chromatogram of tannin standard 4 ppm replication $3 x$

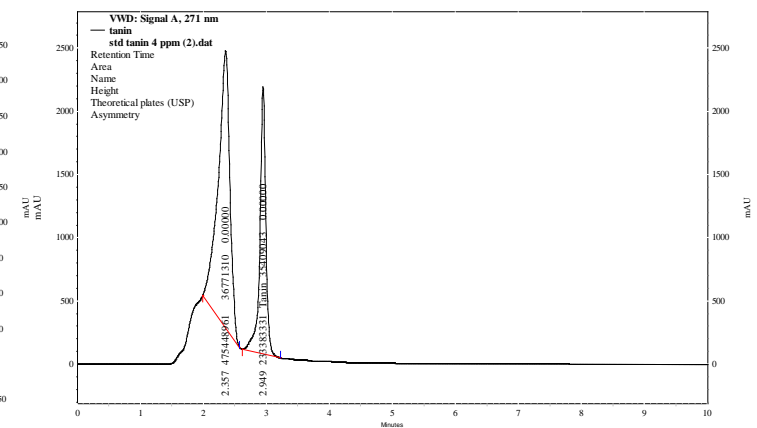

Figure 3. Chromatogram of tannin standard 4 ppm replication $3 x$ (2)

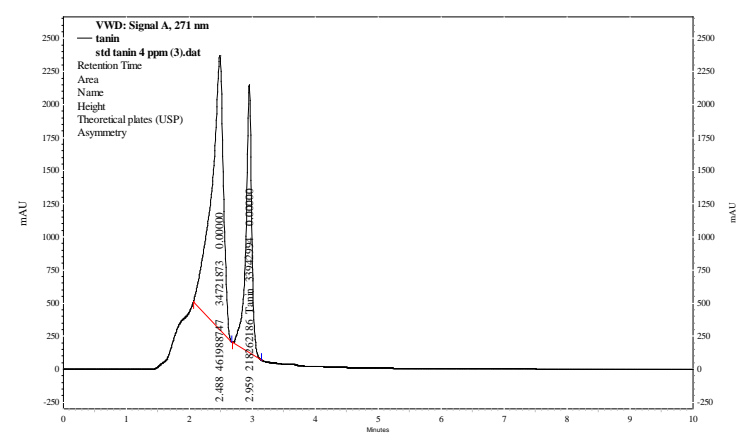

Figure 4. Chromatogram of tannin standard $4 \mathrm{ppm}$ replication $3 \times(3)$

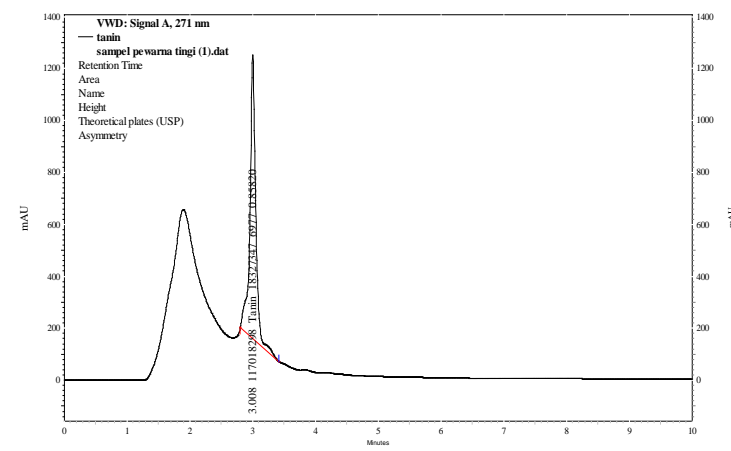

Figure 5. Chromatogram of soga tingi bark (Ceriops tagal) (1)

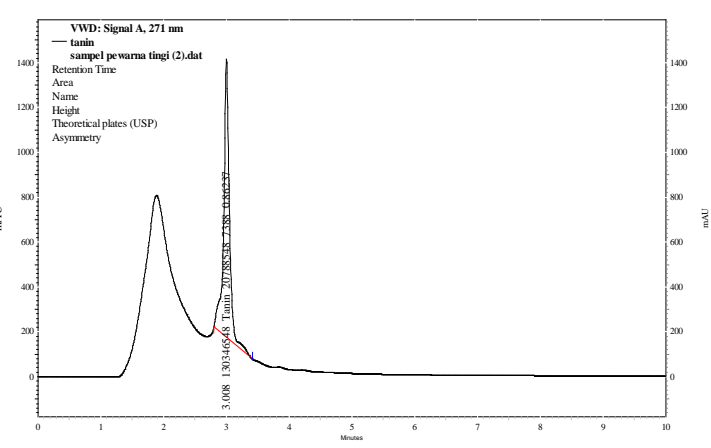

Figure 6. Chromatogram of soga tingi bark (Ceriops tagal) (2) 
Table 2. Analysis Result of Chromatogram of tannin standard

\begin{tabular}{lccc}
\hline \multicolumn{1}{c}{ Sample } & Retention Time $(\mathrm{min})$ & Area & High \\
\hline $\begin{array}{l}\text { Tannin standard } 4 \\
\text { ppm }\end{array}$ & 2.886 & 215585571 & 35292817 \\
$\begin{array}{l}\text { Tannin standard } 4 \\
\text { ppm (2) }\end{array}$ & 2.949 & 233383331 & 35409043 \\
$\begin{array}{l}\text { Tannin standard 4 } \\
\text { ppm (3) } \\
\text { Average }\end{array}$ & 2.959 & 218262186 & 33942994 \\
\hline
\end{tabular}

Table 3. Analysis Result of Chromatogram of tingi bark (Ceriops tagal)

\begin{tabular}{lccc}
\hline \multicolumn{1}{c}{ Sample } & Retention Time (min) & Area & High \\
\hline Tingi natural dyes & 3.008 & 117018298 & 18327347 \\
Tingi natural dyes (2) & 3.008 & 130346548 & 20788548 \\
Average & & 123682423 & \\
\hline
\end{tabular}

With the data that has been obtained from the replica results, it can be calculated the concentration of tannins in natural dyes from the skin of high sugar (Ceriops tagal). The sample is diluted 10 times then taken $1 \mathrm{~mL}$. So that the dilution factor is 10 times. $4 \mathrm{ppm}=222410363 \mathrm{mAU}$ Average average sample area $=123682423 \mathrm{mAU}$ Standard concentration $=4 \mathrm{ppm}=>0.004 \mathrm{mg} / \mathrm{mL} \cdot$ Based on these data calculations can be made as follows:

$$
\begin{aligned}
\text { Tannin conten } & =\frac{123682423 \mathrm{mAU}}{222410363 \mathrm{mAU}} \times 0,004 \frac{\mathrm{mg}}{\mathrm{mL}} \times 10 \\
& =0,022244 \mathrm{mg} / \mathrm{mL} \\
& =22,44 \mathrm{ppm} \text { tanin }
\end{aligned}
$$

Result showed the soga tingi bark (Ceriops tagal) contains tannis 22,44 ppm.

Research conducted by Kasmudjiastuti (2014) in extracts of soga tingi bark (Ceriops tagal) 151.51 grams extracted from soga tingi bark (Ceriops tagal) weighing 4 kilo grams with the method of comparison of bark height with 1:3 solvents obtained levels of tannin amounted to $70.91 \%$. From the results of our research and research conducted by Kasmudjiastuti levels of tannins in the bark of soga tingi (Ceriops tagal) are high enough so that the bark of soga tingi is very good as a natural dye of cloth ,especially batik cloth so as to reduce the use of synthetic dyes that are harmful to the environment and humans.

\section{CONCLUSION}

The FTIR test shows that there are O-H, N-H, C = O, C = C, C-H, NO $2, \mathrm{C}-\mathrm{N}$, and C-O groups in sample of soga tingi bark (Ceriops tagal) which are identified as containing tannin compounds. The tannin content contained in the soga tingi bark (Ceriops tagal) is $22,44 \mathrm{ppm}$.

\section{ACKNOWLEDGMENTS}

The authors gratefully acknowledge the financial support of the Director General of Higher Education Research via PTUPT (2019 -2020) and UMKM Batik Soul Craft Group Kuwiran, Banyudono, Boyolali for giving the opportunity for the research. 


\section{REFERENCES}

[1] Crisholithus, Suro. 2008. Laporan Praktek Kerja Profesi Farmasi Industri di PT. Kimia Farma (Persero) Tbk. Plant Bandung. Sumatra Utara : Universitas Sumatera Utara.

[2] Desmiaty, Y.; Ratih H.; Dewi M.A.; Agustin R. Penentuan Jumlah Tanin Total pada Daun Jati Belanda (Guazuma ulmifolia Lamk) dan Daun Sambang Darah (Excoecaria bicolor Hassk.) Secara Kolorimetri dengan Pereaksi Biru Prusia. Ortocarpus. 2008. 8, 106-109.

[3] Jansen, P. C. M. et al. 2005. Prota 3: Dyes and tannins. Netherland: Wageningen.

[4] Kant, Rita. 2012. Textile dyeing industry an environmental hazard. India: Chandigarh.

[5] Kasmudjiastuti, E. 2014. Karakterisasi kulit kayu tingi (Ceriops tagal) sebagai bahan penyamak nabati. Majalah Kulit, Karet, dan Plastik,30(2): 71.

[6] Marais, J.P.J., B. Deavours, R.A. Dixon, dan D. Ferreira. 2006. The Stereochemistry of Flavonoids. The Science of Flavonoid, USA, pp. 1-273.

[7] Pansera et al. 2004. Extraction Of Tannin By Acacia Mearnsii With Supercritical Fluids. Joumal International Brazilian Archives of Biology and Technology.995-998.

[8] Paryanto, Wibowo,W.A dan Aditya M.H., (2016), Pembuatan Zat Warna Alami dari Buah Mangrove Spesies Rhizopora stylosa sebagai Pewarna Batik Ramah Lingkungan dalam Skala Pilot Plan, Seminar Nasional Teknologi Pengolahan Limbah XIV, BATAN dan Sekolah Ilmu Lingkungan UI, Jakarta, Hal 76 81.

[9] Parubak, A.S., 2013. Senyawa Flavonoid yang Bersifat Antibakteri dari Akway (Drimys becarina Gibbs). Chemistry Progress, 6(1): 34-37.

[10] Pujilestari,T.2015.Sumber dan Pemanfaatan Zat Warna Alam Untuk Keperluan Industri.Dinamika Kerajian dan Batik.32(2).93-106.

[11] Purnomo, M.A.J. 2004. Zat Pewarna Alam sebagai Alternatif Zat Warna yang Ramah Lingkungan. Jurnal Seni Rupa STSI Surakarta, 1(2): 57-61.

[12] Rusila, N.Y., Khazali, M., \& Suryadipura, I. (2012). Panduan Pengenalan Mangrove di Indonesia. Bogor, Indonesia: Ditjen PHKA dan Wetlands International Indonesia Programme.

[13] Susanto, S. 1973. Seni Kerajinan Batik Indonesia, BPKB. Yogayakarta.

[14] Syaifuddin, M. 2011. Pengaruh Aerasi Pada Sianidasi Emas Dari Batuan Mineral. Tugas Akhir Institut Teknologi Sepuluh Nopember.

[15] Visalakshi, M., and Jawaharlal, M. 2013. Healthy Hues-Status and Implication in Industries - Brief Review.Journal of Agriculture and Allied Sciences, 3(2): 42-51.

[16] Yernisa,Gumbira-Sa’id,E.danSyamsu, K.2013.

Aplikasi Pewarna Bubuk Alami dari Ekstrak Biji Pinang (Areca catechu L.) pada Pewarnaan Sabun Transparan. Jurnal Teknologi Industri Pertanian, 23 (3): 190-198. 